\title{
MENINGKATKAN SIKAP EMPATI SISWA SMP MELALUI LAYANAN BIMBINGAN KELOMPOK DENGAN TEKNIK SOSIODRAMA
}

\author{
Novi Andriati ${ }^{1}$, Amelia Atika ${ }^{2}$, Petrus Rico Yuditio ${ }^{3}$ \\ ${ }^{1,2,3}$ Program Studi Bimbingan dan Konseling Fakultas Ilmu Pendidikan dan Pengetahuan Sosial \\ IKIP PGRI Pontianak, Jalan Ampera Nomor 88 Pontianak \\ 1e-mail: Novieandriaty@yahoo.co.id
}

\begin{abstract}
Abstrak
Empati merupakan suatu aktivitas untuk memahami apa yang sedang dipikirkan dan dirasakan orang lain, serta kondisi yang dialami orang lain, tanpa kehilangan kontrol dirinya. Tujuan penelitian yaitu meningkatkan sikap empati siswa melalui layanan bimbingan kelompok dengan teknik sosiodrama di kelas VIII SMP Negeri 1 Sungai Raya Kabupaten Kubu Raya. Metode penelitian menggunakan penelitian tindakan dengan bentuk penelitiannya Penelitian Tindakan Bimbingan dan Konseling (PTBK). Teknik pengumpul data menggunakan teknik observasi langsung, teknik komunikasi langsung, dan teknik komunikasi tidak langsung. Alat pengumpul data menggunakan skala psikologis, pedoman observasi, dan panduan wawancara. Subjek penelitian 8 orang siswa yang dipilih berdasarkan rekomendasi dari guru BK. Hasil penelitiann memperlihatkan bahwa sikap empati siswa sebesar 59,90\%. Proses pelaksanaan layanan bimbingan kelompok dengan teknik sosiodrama dalam meningkatkan sikap empati meliputi tahap pembentukan, peralihan, kegiatan, dan penutup berjalan dengan lancar sesuai dengan perencanaan yang telah dibuat, layanan bimbingan kelompok dengan teknik sosiodrama dapat meningkatkan sikap empati pada siswa sebesar $73,70 \%$.
\end{abstract}

Kata Kunci: sikap empati, layanan bimbingan kelompok, teknik sosiodrama.

\begin{abstract}
Empathy is an activity to understand what others are thinking and feeling, as well as what is thought and felt by those concerned with the conditions experienced by others, without losing control of themselves. This study aimed at improving the attitude of empathy of students through guidance services in groups with sociodrama techniques at the class VIII of SMP Negeri 1 Sungai Raya, Kubu Raya. The research method used in this study is action research, with the form of research is Guidance and Counseling Action Research (PTBK). Data collection techniques used direct observation, direct communication, and indirect communication. Moreover, the data collection tools were psychological scale, observation sheet, and interview guide. The subject of the research was 8 students, based on recommendations from the BK teacher. The results of the study showed empathy for students with $59.90 \%$. The process of implementing group guidance services with sociodrama techniques to increase empathy including the stages of formation, transition, activities, and closing smoothly in accordance with the planning that has been made, sociodrama techniques can increase empathy for students with $73.70 \%$.
\end{abstract}

Keywords: empathy, group guidance services, sociodrama technique.

\section{PENDAHULUAN}

Remaja berasal dari bahasa latin adolensense yang berarti tumbuh atau tumbuh menjadi dewasa. Istilah adolensence mempunyai arti yang lebih luas lagi 
yang mencakup kematangan mental, emosional sosial dan fisik (Hurlock, 2011). Pada masa sekarang sebenarnya tidak mempunyai tempat yang jelas karena tidak termasuk golongan anak tetapi tidak juga golongan dewasa atau tua. Masa remaja menunjukkan dengan jelas sifat transisi atau peralihan karena remaja belum memperoleh status dewasa dan tidak lagi memiliki status anak.

Remaja sedang mengalami apa yang dinamakan proses pencarian identitas diri yang berusaha membangun suatu hubungan interaksi yang sifatnya baru terutama dalam lingkungan sekolah. Salah satu tugas tersulit remaja atau peserta didik adalah menjalin hubungan yang harmonis terhadap orang lain atau penyesuaian sosial. Remaja harus menyesuaikan diri dengan teman sebaya, dengan lawan jenis serta terhadap orang dewasa yang berada di luar lingkungan keluarga dan sekolah. Karakteristik dari perkembangan sosial peserta didik yaitu harus mampu untuk memahami orang lain sebagai individu yang berbeda, baik menyangkut sifat pribadi, minat, nilai-nilai, maupun perasaan.

Salah satu tindakan sekolah pada peserta didik dengan bimbingan konseling yang mengarahkan para peserta didik untuk mengetahui bakat dan potensi dalam dirinya. Bimbingan dan konseling diperlukan untuk membuat individu lebih mandiri dan berkembang secara optimal dalam berbagai bimbingan, seperti bimbingan pribadi, sosial, belajar, dan bimbingan karier melalui berbagai jenis kegiatan bimbingan, sehingga pendidikan dapat berjalan dengan lancar dengan adanya bimbingan dan konseling. Prayitno dan Erman (2010), menyatakan bimbingan adalah proses pemberian bantuan yang dilakukan oleh orang yang ahli kepada seseorang atau beberapa orang individu, baik anak-anak, remaja, maupun dewasa agar orang-orang yang dibimbing dapat mengembangkan kemampuan dirinya sendiri dan mandiri, dengan memanfaatkan kekuatan individu dan sarana yang ada dan dapat dikembangkan berdasarkan norma-norma yang berlaku. Winkel (2009), berpendapat bahwa konseling merupakan serangkaian kegiatan paling pokok dari bimbingan dalam usaha membantu konseli secara tatap muka dengan tujuan agar klien dapat mengambil tanggung jawab sendiri terhadap berbagai persoalan atau masalah khusus. 
Setelah menguraikan definisi tentang bimbingan dan konseling, dari pendapat tersebut definisi Bimbingan dan Konseling (BK) yaitu serangkaian kegiatan berupa bantuan yang dilakukan oleh seorang ahli kepada konseli dengan cara tatap muka, baik secara individu atau beberapa orang dengan memberikan pengetahuan tambahan untuk mengatasi permasalahan yang dialami oleh konseli, dengan cara terus menerus dan sitematis agar permasalahan yang dialami konseli dapat teratasi secara optimal. Dalam bimbingan konseling terdapat beberapa layanan, salah satunya layanan bimbingan kelompok. Layanan bimbingan kelompok merupakan salah satu layanan bimbingan dan konseling berupa bantuan alternatif penyelesaian masalah menggunakan dinamika kelompok dengan tujuan masalah yang dialami individu bisa diselesaikan bersama-sama dan bermanfaat bagi anggota kelompok.

Sitti (2009), menyatakan bimbingan kelompok merupakan salah satu bentuk usaha pemberian bantuan kepada orang-orang yang mengalami masalah. Bimbingan kelompok seharusnya menjadi tempat penempaan sikap, keterampilan, dan keberanian sosial yang bertenggang rasa. Kegiatan kelompok yang dilakukan oleh sekelompok orang dengan memanfaatkan dinamika kelompok yaitu adanya interaksi saling mengeluarkan pendapat, memberikan tanggapan, saran, dan sebagainya, pemimpin kelompok menyediakan informasi-informasi yang bermanfaat agar dapat membantu individu mencapai perkembangan yang optimal. Salah satu teknik yang dapat digunakan pada layanan bimbingan kelompok yaitu teknik sosiodrama.

Sosiodrama adalah permainan peran yang ditujukan untuk memecahkan masalah sosial yang muncul dalam hubungan antar-manusia. Konflik-konflik sosial yang disosiodramakan adalah konflik-konflik yang tidak mendalam dan tidak menyangkut gangguan kepribadian. Kegiatan sosiodrama lebih bertujuan untuk mendidik atau mendidik kembali daripada kegiatan penyembuhan. Sosiodrama biasanya digunakan untuk menangani masalah yang berkaitan dengan masalah sosial seperti krisis kepercayaan diri jika dihadapan kelompok, menumbuhkan rasa kesetiakawanaan sosial dan rasa tanggung jawab serta untuk mengembangkan ketrampilan tertentu (Tatiek, 2006). Berbagai masalah yang 
sering dialami siswa yaitu masalah yang berkaitan dengan sikap empati. Permasalahan empati sangat penting untuk diatasi karena manusia merupakan makhluk sosial yang harus saling memahami dan mengerti satu sama lain.

Empati merupakan suatu aktivitas untuk memahami apa yang sedang dipikirkan dan dirasakan orang lain, serta apa yang dipikirkan dan dirasakan oleh yang bersangkutan terhadap kondisi yang dialami orang lain, tanpa kehilangan kontrol dirinya. Terlepas dari aktivitas untuk memahami orang lain tersebut setiap individu juga harus tetap mempertimbangkan kontrol dirinya, sehingga individu secara sadar bisa malakukan empati dengan tidak hanyut dalam suasana orang lain melainkan memahami apa yang dirasakan orang lain (Taufik, 2012). Aspek empati meliputi kognitif, afektif, dan komunikatif.

Aspek kognitif merupakan aspek yang menimbulkan pemahaman terhadap perasaan orang lain. Pernyataan tersebut berati bahwa aspek kognitif merupakan perwujudan dari multiple dimensions, seperti kemampuan seseorang dalam menjelaskan suatu perilaku, kemampuan untuk mengingat jejak-jejak intelektual dan verbal tentang orang lain, serta kemampuan untuk membedakan atau menyelaraskan kondisi emosional dirinya dengan orang lain. Kemampuan kognitif yang tidak memadai seseorang akan meleset dalam memahami kondisi orang lain (incongruence). Empati sebagai aspek afektif merujuk pada kemampuan menselaraskan pengalaman emosional pada orang lain, empati afektif merupakan suatu kondisi pengalaman emosi seseorang sama dengan pengalaman emosi yang sedang dirasakan oleh orang lain atau perasaan mengalami bersama dengan orang lain. Empati sebagai aspek komunikatif yaitu perilaku yang mengekspresikan perasaan-perasaan empati.

Berdasarkan observasi yang telah peneliti lakukan di SMP Negeri 1 Sungai Raya terdapat siswa yang memperlihatkan sikap tidak empati. Terdapat diskriminasi sosial yang dilakukan siswa kelas VIII. Hal tersebut terjadi ketika kelas mendapatkan tugas untuk dibagi menjadi beberapa kelompok, masih ada beberapa siswa yang tidak mendapat bagian dari kelompok yang ada. Berikutnya, siswa masih sering berkata kasar terhadap teman, saling menyindir. Masalah yang lain, ketika ada seorang teman yang sedang bersedih tetapi tidak ada yang 
menanggapi hal tersebut dan tidak berusaha untuk memahami kesedihan temannya sehingga teman tersebut merasa terhibur.

Hasil penelitian Alan dan Elin (2016), memperlihatkan adalah ada perbedaan tingkat empati siswa kelas VII SMP sebelum dan sesudah diberikan treatment. Sehingga dapat disimpulkan bahwa penggunaan media film efektif untuk meningkatkan sikap empati siswa kelas VII SMP. Yuliandita (2016), menyatakan dalam hasil penelitiannya bahwa adanya peningkatan kemampuan interpersonal siswa setelah menerapkan metode sosiodrama. Siregar (2013), menyatakan dalam hasil penelitiannya bahwa ditemukan sikap pro-sosial siswa berada pada kategori tinggi, namun terdapat siswa dengan tingkat sikap pro-sosial rendah yang ditunjukkan dengan kurangnya untuk menolong, berempati, dan bekerja sama, serta kurangnya beramal. Asti dan Mungin (2017), menyatakan dalam hasil penelitiannya bahwa model bimbingan kelompok telah memenuhi syarat sesuai dengan standar evaluasi suatu produk, yang terdiri dari empat aspek, yaitu kebermanfaatan, keakuratan, kepatutan, dan kemudahan.

\section{METODE}

Metode penelitian yang digunakan dalam penelitian adalah metode penelitian tindakan bimbingan dan konseling (PTBK). PTBK merupakan suatu bentuk penelitian yang dilakukan oleh guru bimbingan dan konseling untuk memecahkan permasalahan sekelompok siswa dengan jalan melakukan tindakan berupa siklus yang harus diterapkan demi peningkatan pelayanan bimbingan dan konseling. Dalam pelaksanaannya, peneliti harus bekerja sama dengan kolaborator, yaitu guru bimbingan dan konseling. PTBK merupakan pengembangan dari penelitian tindakan kelas, yaitu tindakan dalam penelitian dilakukan dalam suatu siklus kegiatan.

Subjek penelitian berjumlah 8 siswa kelas VIII. Pelaksanaan penelitian dilakukan di SMP Negeri 1 Sungai Raya yang berada di Jalan Adisucipto, Kubu Raya. Teknik pengumpul data yang digunakan dalam penelitian yaitu teknik observasi langsung, teknik komunikasi langsung, dan teknik komunikasi tidak langsung. Sedangkan alat pengumpul datanya yaitu skala psikologis, pedoman 
observasi, dan panduan wawancara. Teknik analisis data yang digunakan adalah teknik analisis deskripsi kualitatif dan kuantitatif.

Prosedur dan rencana PTBK terdiri dari beberapa siklus. Siklus merupakan putaran dari suatu rangkaian kegiatan, dimulai dari perencanaan, persiapan, pelaksanaan hingga evaluasi. Tahapan-tahapan penelitian dalam PTBK, yaitu: Perencanaan (Plan). Perencanaan adalah langkah yang digunakan oleh peneliti untuk merancang kegiatan tindakan. Perencanaan tindakan terdiri dari: (1) Penentuan subjek penelitian, yaitu menentukan orang-orang yang terlibat dalam pelaksanaan kegiatan bimbingan kelompok; (2) Menentukan kolaborator, yaitu menentukan orang yang akan bekerja sama dalam membantu peneliti; (3) Membuat rencana pemberian layanan, yaitu merumuskan rancangan skenario pelaksanaan layanan bimbingan kelompok; (4) Menyiapkan pedoman observasi layanan bimbingan kelompok dengan teknik sosiodrama; dan (5) Perencanaan merupakan langkah yang sangat penting bagi peneliti di dalam merancang penelitian agar penelitian yang dilaksanakan mendapatkan hasil yang optimal.

Pelaksanaan (Action), setelah pada tahap sebelumnya peneliti membuat perencanaan, maka tahap selanjutnya adalah pelaksanaan dari berbagai perencanaan yang telah disusun sebagai berikut: (1) Tahap pembentukan. Merupakan tahap awal membentuk dinamika kelompok. Pada tahap pembentukan harus diciptakan keakraban dari semua anggota kelompok. Pada umumnya para anggota saling memperkenalkan diri dan juga mengungkapkan tujuan ataupun harapan-harapan yang ingin dicapai baik oleh masing-masing, sebagian, maupun seluruh anggota kelompok; (2) Tahap peralihan, setelah tahap pertama dilaksanakan dengan baik, maka tahap peralihan dimanfaatkan sebagai suatu pemantapan terhadap antusiasme peserta didik dalam kelompok untuk melanjutkan kegiatan tanpa ada rasa kebosanan. Tahap peralihan merupakan masa peralihan anggota kelompok dari tahap pembentukan ke tahap selanjutnya yaitu tahap kegiatan.

Kegiatan. Tahap kegiatan merupakan tahap dari pelaksanaan bimbingan kelompok dengan teknik sosiodrama yang akan menentukan hasil yang menjadi tujuan dalam penelitian, yaitu untuk meningkatkan sikap empati siswa. Kegiatan 
yang dilakukan membahas serta memainkan peran secara mendalam dan tuntas.Tahap kegiatan merupakan inti dari kegiatan kelompok, maka aspek-aspek yang menjadi isi dan pengiringnya cukup banyak dan aspek-aspek tersebut perlu mendapat perhatian yang seksama dari pemimpin kelompok. Tahap kegiatan mendapatkan alokasi waktu yang terbesar dalam keseluruhan anggota kelompok.

Pengakhiran. Tahap pengakhiran merupakan tahap penutup dalam kegiatan bimbingan kelompok. Masing-masing anggota kelompok mengungkapkan pesan dan kesannya setelah mengikuti kegiatan kemudian dikaitkan dengan kegiatan berikutnya. Dibahas juga tentang kegiatan lanjutan, jika pada siklus pertama belum berhasil, maka dilanjutkan pada siklus kedua agar permasalahan yang diselesaikan tuntas. Pengamatan (Observation). Pengamatan dalam penelitian tindakan bimbingan konseling dilakukan sepanjang peneliti melakukan tindakan. Pelaksanaan pengamatan tindakan bimbingan dan konseling harus merujuk kepada indikator keberhasilan yang telah ditetapkan dalam tahap perencanaan. Oleh karenanya pengamatan dapat dikelompokkan menjadi dua macam yaitu pengamatan terhadap proses dan hasil.

Pengamatan terhadap proses adalah pengamatan yang dilakukan terhadap berbagai data yang muncul berkaitan dengan proses kegiatan pemberian tindakan dalam PTBK. Pengamatan dilakukan terhadap peneliti dan aktivitas siswa selama kegiatan bimbingan kelompok berlangsung. Pengamatan terhadap data proses dilakukan sepanjang tindakan diberikan, mulai dari awal pertemuan tindakan sampai akhir pertemuan tindakan. Pengamatan terhadap hasil tindakan, dilakukan untuk melihat keberhasilan tindakan terhadap variabel masalah dalam PTBK, yaitu meningkatkan sikap empati siswa melalui layanan bimbingan kelompok, maka data hasil yang harus peneliti amati (ukur) adalah tentang sikap empati.

Refleksi (Reflection). Refleksi dalam PTBK dilakukan setelah berbagai macam data terkumpul. Refleksi dilakukan dengan maksud untuk mengetahui sejauh mana tingkat pencapaian tindakan dalam mengatasi masalah. Apabila pada siklus tindakan I masalah belum terselesaikan/belum ada perubahan, maka akan dilanjutkan pada siklus berikutnya. Tetapi jika sudah terdapat perubahan/masalah 
sudah terselesaikan, maka siklus dihentikan. Gambaran proses siklus pelaksanaan tindakan dapat dilihat pada gambar berikut.

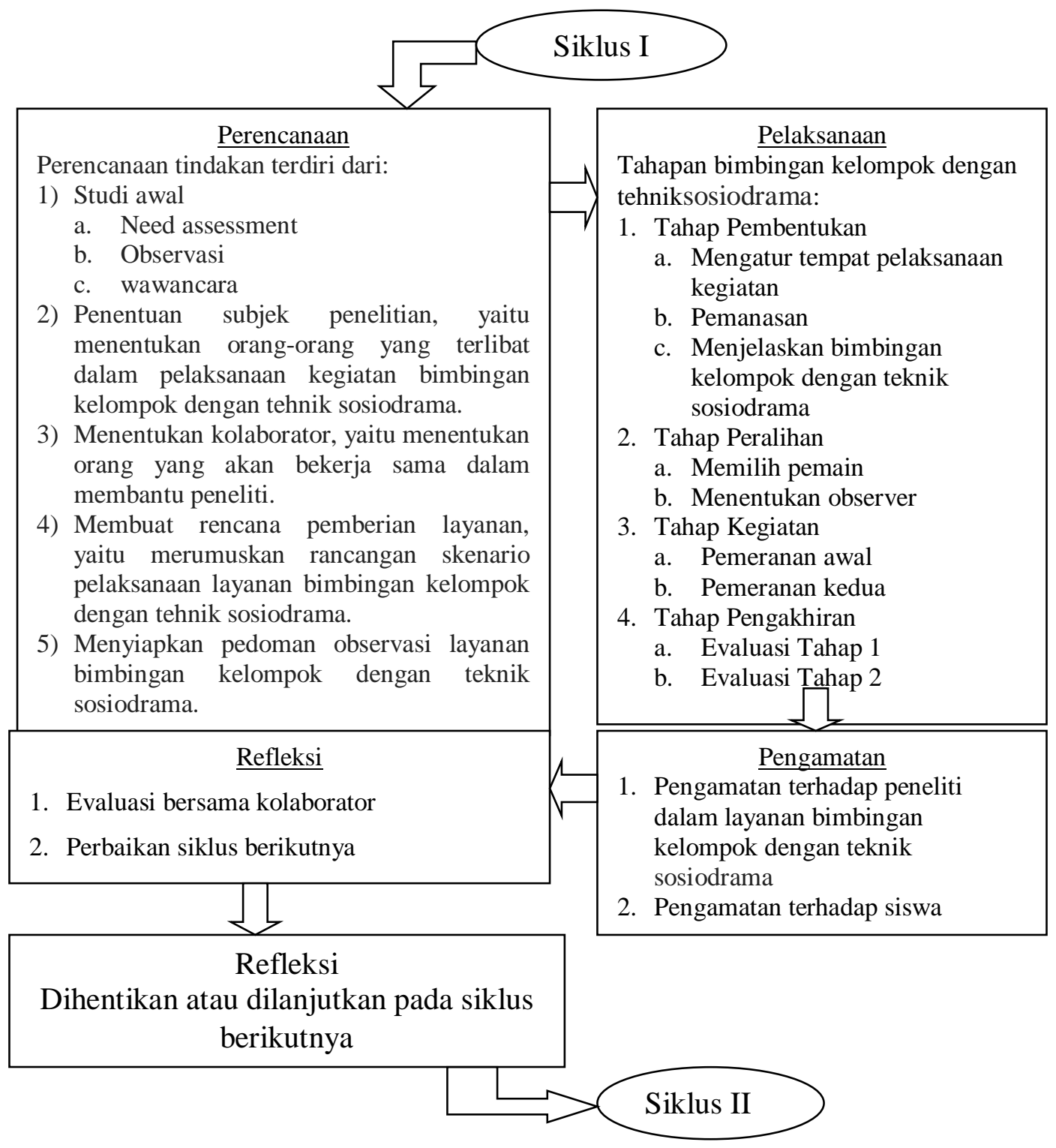

\section{Gambar 1 Siklus Pelaksanaan Tindakan}

\section{HASIL DAN PEMBAHASAN}

\section{Sikap Empati Siswa}

Gambaran awal sikap empati siswa SMP Negeri 1 Sungai Raya Kabupaten Kubu Raya dapat dilihat pada tabel berikut. 
Tabel 1 Hasil Skala Psikologis Sikap Empati Sebelum Tindakan

\begin{tabular}{llcccc}
\hline No & Aspek Variabel & Skor Aktual & $\begin{array}{c}\text { Skor } \\
\text { Ideal }\end{array}$ & $\begin{array}{c}\text { Persentase } \\
(\%)\end{array}$ & Kategori \\
\hline 1 & Kognitif & 294 & 480 & $61,25 \%$ & Sedang \\
\hline 2 & Afektif & 109 & 192 & $56,80 \%$ & Sedang \\
\hline 3 & Komunikatif & 28 & 48 & $58,30 \%$ & Sedang \\
\hline Jumlah & 431 & 720 & $59,90 \%$ & Sedang \\
\hline
\end{tabular}

Berdasarkan Tabel 1, dapat diinterprestasikan sebagai berikut: (1) Aspek kognitif mendapat perolehan skor aktual 294 dari skor ideal 480 dengan persentase $61,25 \%$ dalam kategori "sedang". Dengan demikian, dapat diinterprestasikan bahwa siswa kelas VIII SMP Negeri 1 Sungai Raya Kabupaten Kubu Raya, belum bisa memahami perasaan orang lain dan belum menimbulkan sikap empati yang tinggi; (2) Aspek afektif mendapat perolehan skor aktual 109 dari skor ideal 192 dengan presentase 56,80\% dalam kategori “sedang”. Demikian dapat diinterprestasikan bahwa siswa kelas VIII SMP Negeri 1 Sungai Raya Kabupaten Kubu Raya, belum bisa menyelaraskan pengalaman emosional kepada orang laindan belum menimbulkan sikap empati yang tinggi; (3) Aspek komunikatif mendapat perolehan skor aktual 28 dari skor ideal 48 dengan presentase 58,30\% dalam kategori "sedang". Demikian dapat diinterprestasikan bahwa siswa kelas VIII SMP Negeri 1 Sungai Raya Kabupaten Kubu Raya, belum bisa mengekspresikan perasaan-perasaan empati dan belum menimbulkan sikap empati yang tinggi.

\section{Pelaksanaan Layanan Bimbingan Kelompok dengan Teknik Sosiodrama}

Proses pelaksanaan layanan bimbingan kelompok dengan teknik sosiodrama dalam meningkatkan sikap empati meliputi tahap pembentukan, peralihan, kegiatan, dan penutup. Data skala psikologis yang diambil dari subjek penelitian sebelum dan setelah dilaksanakannya tindakan penelitian dengan teknik sosiodrama pada siklus I dan siklus II, peningkatan sikap empati siswa dapat dilihat pada tabel berikut. 
Tabel 2 Persentase Peningkatan Sikap Empati Sebelum, Siklus I, dan II

\begin{tabular}{ccccc}
\hline No & Aspek & Sebelum & Siklus I & Siklus II \\
\hline 1 & Kognitif & $61,25 \%$ & $64,30 \%$ & $73,75 \%$ \\
2 & Afektif & $56,80 \%$ & $65,60 \%$ & $73,40 \%$ \\
3 & Komunikatif & $58,30 \%$ & $64,60 \%$ & $72,90 \%$ \\
\hline
\end{tabular}

Berdasarkan Tabel 2, terlihat perbandingan sikap empati siswa sebelum dan sesudah dilakukannya tindakan sosiodrama, baik di siklus I maupun di siklus II terus mengalami peningkatan disetiap aspeknya, dengan rincian sebagai berikut: (1) Aspek kognitif sebelum tindakan diperoleh persentase $61,25 \%$ dengan kategori "sedang", setelah dilaksanakan tindakan siklus I meningkat menjadi 64,30\% namun masih termasuk kategori "sedang" dan setelah dilaksanakan siklus II meningkat menjadi 73,75\% dengan kategori "tinggi"; (2) Aspek afektif sebelum tindakan diperoleh presentase 56,80\% dengan kategori "sedang", setelah dilaksanakan tindakan siklus I meningkat menjadi 65,60\% termasuk kategori "sedang" dan setelah dilaksanakan siklus II semakin meningkat menjadi 73,40\% dengan kategori "tinggi"; dan (3) Aspek komunikatif sebelum tindakan diperoleh presentase 58,30\% dengan kategori "sedang", setelah dilaksanakan tindakan siklus I meningkat menjadi 64,60\% namun masih termasuk kategori "sedang" dan setelah dilaksanakan siklus II meningkat menjadi 72,90\% dengan kategori "tinggi".

Dari uraian tersebut, dapat disimpulkan bahwa teknik sosiodrama dapat meningkatkan sikap empati siswa kelas VIII SMP Negeri 1 Sungai Raya Kabupaten Kubu Raya dengan kategori "tinggi”, sehingga teknik sosiodrama dapat dijadikan panduan guru bimbingan dan konseling untuk mengatasi permasalahan peserta didik di SMP Negeri 1 Sungai Raya Kabupaten Kubu Raya khususnya dan di sekolah-sekolah lain pada umumnya. Layanan bimbingan kelompok dengan teknik sosiodrama merupakan salah satu layanan dalam bimbingan dan konseling yang bertujuan untuk membantu peserta didik meningkatakan sikap empati pada dirinya dengan cara melakukan drama, sehingga peserta didik menjadi siswa yang mampu mengontrol diri, memahami orang lain, peka terhadap sekitar dan peduli terhadap orang lain. 
Berdasarkan hasil observasi dan panduan wawancara yang dilakukan bersama guru BK, layanan bimbingan kelompok dengan teknik sosiodrama pada siklus I dan II terdapat peningkatan sikap empati berdasarkan aspek-aspeknya. Sejalan dengan hasil penelitian Emi (2016), bahwa konseling kelompok dengan teknik sosiodrama yang diterapkan oleh peneliti dapat meningkatkan sikap empati siswa. Siswa terlihat antusias dan percaya diri, layanan sangat memengaruhi keefektifan layanan tersebut, penggunaan bahasa yang sederhana akan lebih mudah dipahami oleh peserta layanan sehingga layanan yang diberikan akan berjalan dengan efektif.

\section{SIMPULAN}

Sikap empati pada siswa sebelum diberikan tindakan layanan bimbingan kelompok dengan teknik sosiodrama persentasenya 59,90\%. Hal tersebut dilihat dari analisis hasil skala psikologis sebelum diberikan tindakan. Proses pelaksanaan layanan bimbingan kelompok dengan teknik sosiodrama dalam meningkatkan sikap empati meliputi tahap pembentukan, peralihan, kegiatan, dan penutup berjalan dengan lancar sesuai dengan perencanaan yang telah dibuat. Layanan bimbingan kelompok dengan teknik sosiodrama dapat meningkatkan sikap empati pada siswa dengan persentase $73,70 \%$.

\section{DAFTAR PUSTAKA}

Alan, A. \& Elin, F. 2016. Efektivitas Penggunaan Media Film untuk Meningkatkan Empati Siswa Kelas VII SMP. Jurnal Kajian Bimbingan dan Konseling, 1(1): 19-26.

Asti \& Mungin. 2017. Model Bimbingan Kelompok Teknik Sosiodrama untuk Meningkatkan Empati Siswa SMP. Jurnal Bimbingan dan Konseling, 6(1): 28-33.

Emi. 2016. Meningkatkan Rasa Empati Siswa melalui Layanan Konseling Kelompok dengan Teknik Sosiodrama pada Siswa Kelas XI IPA 3 SMA 2 Kudus. Jurnal Konseling Gusjigang, 2(2): 60-71.

Hurlock. 2011. Psikologi Perkembangan. Alih bahasa oleh Soedjarmo \& Istiwidayanti. Jakarta: Erlangga.

Prayitno \& Erman, A. 2016. Konseling Profesional yang Berhasil. Jakarta: Raja Grafindo Persada. 
Siregar. 2013. Penerapan Metode Sosiodrama untuk Meningkatkan Kemampuan Interpersonal Siswa Kelas VII SMP Negeri 5 Depok Sleman. Jurnal Konseling, 1(2): 32-44.

Sitti. 2009. Konsep Dasar Bimbingan Kelompok. Bandung: Refika Aditama.

Tatiek, R 2006. Teori dan Praktek Bimbingan Kelompok. Malang: Universitas Negeri Malang.

Taufik. 2012. Empati Pendekatan Psikologi Sosial. Jakarta: PT Raja Grafindo Persada.

Winkel. 2009 Bimbingan dan Konseling di Institusi Pendidikan. Yogyakarta: Paramitra.

Yuliandita. 2016. Pengaruh Layanan Bimbingan Kelompok Terhadap Peningkatan Pemahaman Self-Control Siswa Kelas IX di SMP N 1 Wanasari Kabupaten Brebes. Jurnal Pendidikan Konselin,. 2(2): 67-83. 